\title{
Depression and self-esteem of patients positive for HIV/AIDS in an inland city of Brazil
}

\author{
Carolina Castrighini ${ }^{1}$, Elucir Gir ${ }^{1}$, Lis Neves ${ }^{1 *}$, Renata Reis ${ }^{2}$, Marli Galvão ${ }^{3}$, Myeko Hayashido ${ }^{1}$ \\ From $16^{\text {th }}$ International Symposium on HIV and Emerging Infectious Diseases \\ Marseille, France. 24-26 March 2010
}

\section{Background}

Psychiatric disorders are common in the course of HIV infection, and depression is one of the most prevalent. Another consequence is the decrease in self-esteem of the individual, marked by the accumulation and fat loss in areas of the body, one of the side effects of drugs. This study aims to characterize aspects demographics, economics, clinical and epidemiological and identify symptoms of depression and assess self-esteem in individuals with HIV/AIDS at different stages of infection.

\section{Methods}

Descriptive and quantitative study, conducted in an inland city of Sao Paulo (Brazil). Data were collected through interviews with individuals with HIV/AIDS, using as instruments Beck Depression Inventory, Scale of selfesteem by Rosenberg and a questionnaire with data economic, demographic, clinical and epidemiological data.

\section{Results}

We interviewed 75 individuals, and $50.7 \%$ were male. The predominant age group was between 29 and 39 years (42.7\%), 69.3\% reported having been infected through sex; sexual orientation, $92 \%$ is held as heterosexual. Identified that $22(29.4 \%)$ had depressive symptoms and as such, $4(18.1 \%)$ with symptoms of mild to moderate, $6(27.2 \%)$ with moderate to severe and 12 $(54.5 \%)$ with severe symptoms. The self-esteem was identified scores of 14 to 23 of which $34.7 \%$ had a score of 16 points, which indicates low self-esteem.

\section{Discussion}

The analysis of data showed that the individuals interviewed are young, most were infected through sexual

\footnotetext{
* Correspondence: lisapneves@yahoo.com.br

'São Paulo University - School Of Nursing Ribeirão Preto, Ribeirão Preto,
} Brazil intercourse and almost 30\% had depressive symptoms and low self-esteem. The depression associated with anxiety reflects a detrimental effect on quality of life of the individual with HIV/AIDS, with it's extremely important to invest in media and treatments to relieve pain and suffering of the individual. Regarding selfesteem, their confidence levels influence the personal care and take the individual to not seeking treatment. The correct diagnosis is essential for the proper treatment of these patients to increase adherence and improve the quality of life.

\section{Author details}

${ }^{1}$ São Paulo University - School Of Nursing Ribeirão Preto, Ribeirão Preto, Brazil. ${ }^{2}$ Alagoas Federal University, Maceió, Brazil. ${ }^{3}$ Ceará Federal University, Fortaleza, Brazil.

Published: 11 May 2010

\section{doi:10.1186/1742-4690-7-S1-P66}

Cite this article as: Castrighini et al:: Depression and self-esteem of patients positive for HIV/AIDS in an inland city of Brazil. Retrovirology 2010 7(Suppl 1):P66.

\section{Submit your next manuscript to BioMed Central and take full advantage of: \\ - Convenient online submission \\ - Thorough peer review \\ - No space constraints or color figure charges \\ - Immediate publication on acceptance \\ - Inclusion in PubMed, CAS, Scopus and Google Scholar \\ - Research which is freely available for redistribution \\ Submit your manuscript at www.biomedcentral.com/submit}

